\title{
Implications of children's rights for military justice in the context of members of the armed forces younger than the age of eighteen
}

\section{Gus Waschefort}

\begin{abstract}
A number of states internationally lawfully enlist persons younger than eighteen (but at least sixteen) into their national armed forces. While such enlistment is consistent with the relevant states' international law obligations, a number of additional obligations are triggered that the state owe towards the child enlistee by virtue of international children's rights. This article engages with these additional obligations as they apply to child members of the armed forces who are in conflict with the law. In particular, focus is placed on states that maintain a separate and distinct military justice system, and the examples of Australia, Canada and the United Kingdom are relied upon for illustrative purposes. In order to properly engage with state obligation in this regard, the article also endeavors to address the nature of the duty of care owed by the armed forces in respect of child members.
\end{abstract}

Key words: military justice; children's rights; children in the military; child recruitment; child soldier; duty of care; child members of the armed forces

\section{Introduction}

The phenomenon of child soldiers is one that has captured the imagination of millions of people. In the mind's eye of the public at large, the child soldier is a young boy or girl who are recruited against their will, and who are at once subjected to, and forced to perpetrate the most extreme violence. While this is indeed the reality for far too many young people, as the tragic case of Dominic Ongwen well illustrates, ${ }^{1}$ it is certainly not an accurate portrayal of most children who have been enlisted into armed forces or groups (child enlistment). ${ }^{2}$ The recent cutting-edge scholarship on the issue of child enlistment go to some lengths to emphasize that the realities of children are very different, both in regards to the context in which they are recruited or indeed volunteer for service, but also as regards their individual cognitive decision making ability. ${ }^{3}$ In essence, the uni-dimensional view of a child as an

\footnotetext{
${ }^{1}$ Ongwen is charged with seventy counts of war crimes and crimes against humanity, and his trial before the International Criminal Court (ICC) commenced on 6 December 2016. According to his testimony during his first appearance before the ICC he was abducted by the Lord's Resistance Army (LRA) aged fourteen during 1988. See, The Prosecutor v. Dominic Ongwen ICC-02/04-01/15.

2 Indeed, a majority of child enlistees and recruits consider themselves to be volunteers. See, Gus Waschefort, International Law and Child Soldiers (Oxford: Hart, 2015), p. 46-47.

${ }^{3}$ Ibid, at 44-52; David M. Rosen, Armies of the Young: Child Soldiers in War and Terrorism (New Brunswick, NJ: Rutgers University Press, 2005), p. 133.
} 
innocent and passive victim has been convincingly challenged. ${ }^{4}$ However, the recognition of the agency and participatory rights of the child have not supplanted the protective dimensions of international child rights.

One dimension of child recruitment that has escaped academic attention altogether, is that of a child, being a person younger than eighteen, lawfully enlisted into a professional national armed force. A number of states have consistently argued that in order to maintain a non-conscript, professional armed force, they have to recruit persons younger than eighteen. ${ }^{5} \mathrm{~A}$ recent example is the increased recruitment of seventeen-year-olds by the German Bundeswehr, during 2011 the Bundeswehr recruited 689 seventeen year olds, whereas during 2015 this number had more than doubled to 1576 , which accounts for more than 7 percent of recruits for $2015 .^{6}$ This increase in recruitment of seventeen-years-olds appear to be linked to the fact that Germany did away with conscription during 2011, and have moved towards an all-volunteer, professional armed force. The United Kingdom (UK) is also a prominent example in this regard, as it accepts applications for enlistment from fifteen-year-olds, and allows formal enlistment from age sixteen. ${ }^{7}$ Indeed, for the twelvemonth period ending 30 September 2016, sixteen-year-olds made up the single largest age group of new recruits into the British Army. ${ }^{8}$ There are a significant number of states internationally that allow voluntary enlistment by persons younger than eighteen (generally from age seventeen). For purposes of the present article the practices of Australia; Canada; and the UK will be considered. The criteria for inclusion are: the state is party to both the Convention on the Rights of the Child (CRC) and the Optional Protocol to the Convention on the Rights of the Child on the Involvement of Children in Armed Conflict (CRC Protocol) $;{ }^{9}$ the

\footnotetext{
${ }^{4}$ See for example, Daniel P. Keating, 'The Evolving Capacities of the Child: Neurodevelopment and Children's Rights' in Martin D. Ruck, Michele Peterson-Badali and Michael Freeman (eds.), Handbook of Children's Rights (Abingdon: Routedge, 2016), pp. 184-200.

${ }^{5}$ See for example, the Declaration of the United Kingdom entered on upon ratification of the Optional Protocol to the Convention on the Rights of the Child on the Involvement of Children in Armed Conflict (entered into force 12 February 2002) 2173 UNTS 222.

6 'German army has record number of underage soldiers' The Local (10 November 2016), http://www.thelocal.de/20161110/german-army-has-record-number-of-underage-soldiers, accessed on 20 March 2017.

${ }^{7}$ See, http://army.mod.uk/join/join.aspx, accessed on 20 March 2017.

8 'UK Armed Forces Biannual Diversity Statistics 2016', Ministry of Defence (MoD), (1 October 2016), Table 8a, https://www.gov.uk/government/statistics/uk-armed-forces-biannual-diversity-statistics2016, accessed on 20 March 2017.

${ }^{9}$ Convention on the Rights of the Child (entered into force 2 September 1990) 1577 UNTS 3 (CRC). The US is excluded from analysis due to the fact that it is not a state party to the CRC. This is relevant because the norms regarding juvenile justice that will be considered emanates, in large part, from the CRC.
} 
state lawfully enlists persons younger than eighteen; the state maintains a professional, nonconscript armed force; and military justice is maintained through a military system. ${ }^{10}$

While, depending on the relevant states treaty obligations, the enlistment of persons younger than eighteen is lawful, such enlistment does have implications for state obligations in terms of conventional and customary children's rights. While, in the context of child enlistment, there are broader conceptual questions to be asked of the application of the 'best interest of the child' principle specifically in regards to the exercise of general civil and political rights, for example, the right to express one's opinion freely, ${ }^{11}$ and freedom of assembly; ${ }^{12}$ particular issues that arise in regards to states' international child rights obligations include: the obligation to protect children from harm, and particularly sexual violence $;^{13}$ and state obligations in respect of persons younger than eighteen who are in conflict with the law. ${ }^{14}$ This article will focus on the latter.

In this article I engage with the lex lata, and I do not pass judgment on the prevailing international standards on child enlistment, instead I accept that they indeed are the applicable legal standards, and as such I engage with what the implications of these standards are. The first part of the article will determine the scope of lawful enlistment of persons younger than eighteen. Thereafter, the legal relationship between the child enlistee and the armed forces will be considered. Finally, the enquiry will shift to the rights of child enlistees who are subjected to the military justice system. Included in the analysis are both prosecutions for criminal conduct by way of courts-martial, as well as the maintenance of discipline within the force through summary proceedings.

\section{The Lawful Military Enlistment of Persons Younger than Eighteen}

There is in all likelihood a majority of people among the general public in states in which the armed forces recruit persons younger than eighteen that are of the view that such enlistment should not be allowed. There has been a strong international campaign, driven by nongovernmental organizations (NGOs) and quasi-judicial bodies, such as the United Nations (UN) Committee on the Rights of the Child (CRC Committee), calling on states to elevate their recruitment age to eighteen - the so-called "straight-18 consensus". ${ }^{15}$ This campaign is

\footnotetext{
${ }^{10}$ Where military justice is maintained through civilian courts, such as the case of Germany, the issue of child rights in the context of juvenile justice becomes less problematic, as civilian criminal courts invariably deal with these matters as a matter of course.

${ }^{11}$ Article $13(1)$ of the CRC.

${ }^{12}$ Article 15(1) of the CRC.

${ }^{13}$ Article $19(1)$ of the CRC.

${ }^{14}$ Articles 37 and 40 of the CRC.

${ }^{15}$ Waschefort, International Law and Child Soldiers, pp. 3-5.
} 
based, for the most part, on a values-based approach to children's rights, in terms of which age thresholds are based on societal perceptions of appropriateness, without much real attention being paid to an instrumentalist perspective, which is grounded in developmental and neurodevelopmental understandings of cognitive decision making. In pursuit of the straight-18 consensus soft law standards have been developed, for example, the Paris Principles and Guidelines on Children Associated with Armed Forces or Armed Groups, which give a very broad definition of "children associated with armed forces or groups". ${ }^{16}$ These developments often conflate a mainstream view with international legal standards. While soft law can play an incredibly important role in the development of international law, the value of soft law norms is significantly reduced in an area where there are wellestablished hard law norms that regulate the issue at hand. This is even more so in a context where the hard law predates the soft law - as is the case with child enlistment.

As mentioned, the concept "child soldier" illicit an emotive response, and from a legal perspective is not very useful, as there are a significant number of different legal standards that may apply to a given state, depending on that states treaty obligations emanating from international humanitarian law (IHL), international human rights law (IHRL) (both regional and universal) and international criminal law (ICL). Additionally the generic concept of "child soldier" implies that the various elements of the prohibition, being use, recruitment and enlistment, amount to the same violation. The reality is that the experience of, and concerns in regards to, a sixteen year old lawfully enlisted by a professional armed forces are worlds apart from that of a sixteen year old used for direct participation in hostilities by a non-state armed actor, such as the notorious Lords Resistance Army. In terms of both law and practice a significant distinction exists between the notions of the prohibition of the use of children for direct participation in hostilities (DPH), their compulsory conscription, and their voluntary enlistment or recruitment. ${ }^{17}$ In the present article, I am concerned only with the parameters of the lawful voluntary enlistment of persons younger than eighteen. The scholarly debate and work that has been conducted on this prohibition focuses on determining what is prohibited, not what is lawful. In this analysis the focus is on determining what the boundaries are of lawful enlistment of persons younger than eighteen.

While the enlistment of persons younger than eighteen is restricted in a number of international instruments, the most recent development came with the adoption of the CRC Protocol during 2000. At the time of writing this instrument had attained 166 instruments of

\footnotetext{
${ }^{16}$ Article 2(1) of the Paris Commitments and the Principles and Guidelines on Children Associated with Armed Forces or Armed Groups (2007).

${ }^{17}$ For a detailed discussion see Waschefort, International Law and Child Soldiers, pp. 122-131.
} 
ratification, which includes Australia, Canada and the UK. The CRC Protocol also sets the highest bar for the lawful recruitment of persons younger than eighteen. ${ }^{18}$ As such, the present discussion will be focused exclusively on the CRC Protocol.

A key aim of the Protocol was to increase the age threshold from younger than fifteen to younger than eighteen. A number of NGOs mobilized in support of this movement, and called for the "straight-18 consensus". However, in the drafting of the Protocol it soon emerged that a number of key states, including the US and the UK, will not ratify the Protocol should they not be allowed to voluntarily enlist persons younger than eighteen. The drafters were thus left with a choice: either compromise on the straight-18 consensus and attract broader support for the Protocol, or stick to the straight-18 consensus, but lose the support of key states. The drafters opted to be inclusive, and in so doing compromised on their objectives. The result is an instrument which requires states to take all feasible measures to ensure that persons younger than eighteen do not take a direct part in hostilities; ${ }^{19}$ prohibits states from compulsory recruiting (ie conscripting) persons younger than eighteen; ${ }^{20}$ but allows states to voluntarily enlist persons as young as sixteen. ${ }^{21}$ Moreover, the Protocol requires that, at the time of ratification the state party must deposit a declaration "that sets forth the minimum age at which it will permit voluntary recruitment", and the declaration must contain "a description of the safeguards it has adopted to ensure that such recruitment is not forced or coerced". ${ }^{22}$ The minimum safeguards are: recruitment must be genuinely voluntary; recruitment must be carried out with the informed consent of the person's parents or legal guardians; the person must be fully informed of the duties involved in military service; and the person must provide reliable proof of age prior to acceptance into national military service. ${ }^{23}$

Controversially, the Protocol provides for differing obligation applicable to non-state actors. ${ }^{24}$

Upon ratifying the CRC Protocol, Australia; Canada and the UK have each entered a declaration stating that their minimum age of recruitment is sixteen (UK and Canada) ${ }^{25}$ or

\footnotetext{
${ }^{18}$ The African Charter on the Rights and Welfare of the Child (1990) OAU Doc CAB/ LEG/24.9/49 (entered into force 29 November 1999) provides for a higher protective standard, however, this instrument finds application only in Africa.

${ }_{20}^{19}$ Article 1 of the CRC Protocol.

${ }^{20}$ Article 2 of the CRC Protocol.

${ }^{21}$ Article 3(1) of the CRC Protocol.

${ }^{22}$ Article 3(2) lbid.

${ }^{23}$ Article 3(3) Ibid.

${ }^{24}$ See, Waschefort, International Law and Child Soldiers, pp. 95-96.

${ }^{25}$ While in practice the Canadian Forces enlist from age seventeen, their declaration states a minimum enlistment age of sixteen.
} 
seventeen (Australia). Each of these states also specifically indicated in their respective declarations that they have in place all the safeguards required by article $3(3)$ of the Protocol. In order to ensure that the enlistment is genuinely voluntary, that parental consent is informed, and to comply with the requirements that the person be "informed of the duties involved in such military service", extensive information has to be provided to both the applicant and her or his parent(s), including: the lengths of service commitment; if and when windows arise to exit the service; and the specific dangers to which the applicant may be exposed. Such dangers occur in training, but also, it is important to note that in the context of membership to a national armed force, and specifically in the context of an international armed conflict (IAC), the prohibition of using children for DPH does not protect such children from being targeted by opposing forces. Targeting members of a party to an IAC is done on a status-based determination, not a functional determination.

\section{The Relationship between the Child and Armed Forces}

Defining the relationship between the child and the armed forces is important, for a number of reasons: this impacts upon the extent to which the armed forces are able make decisions in respect of the child, such as medical decisions; it also may impact upon the extent to which a parent or guardian can exercise their rights in respect of the child once a service member. Often children are in need of, and receive parental assistance once they interact with the criminal justice system, making this issue of particular relevance for the current discussion. While the legal relationship between the child and schools and universities have often been debated and the subject of litigation, the relationship between the child and the armed forces have not been contemplated in any detail. This raises the question what the duty of care is that a state must exercise in respect of a service members younger than eighteen, in light of the significant control exercised by the armed forces in respect of the service member. One option would be, for example, to deem the armed forces in loco parentis in respect of the service member. ${ }^{26}$

\section{The International Law Dimension: Cognitive Development and the Evolving Capacities of the Child}

Earlier a distinction was made between a values-based approach to setting concrete age thresholds for child rights, and an instrumentalist approach. The former is premised in the idea that societal perceptions of justness have emerged that dictates age-appropriate conduct and entitlement. In contrast, the latter is premised on the idea, in its more moderate

\footnotetext{
${ }^{26}$ The in loco parentis doctrine is a doctrine that emanates from the British Common Law, that literally translates into "in the place of a parent". This doctrine speaks to the duty of care, and often the right to maintain discipline by a defined third party, such as a teacher, in respect of a child.
} 
form, that age thresholds should be determined by developmental and neurodevelopmental evidence on cognitive decision making ability, and in its more extreme form, that the unique characteristics of the child should be considered to determine age-appropriate conduct and entitlement. As will be seen, the CRC accommodates both approaches.

Looking to neurodevelopmental studies for a benchmark on determining age categories for legal standards makes inherent sense. Nevertheless, it is only recently that real effort has been made to align the epistemology of the study of neurodevelopment with that of child rights in order to reach better conclusions on the capacity of children for purposes of materializing rights. Such epistemological alignment allows for reliance on neurodevelopmental research into child cognitive development in the context of the child rights discourse. Keating, a developmental scientist, suggests that in order to reach more compelling conclusions on the cognitive abilities of adolescents, while still not definitive, we have to draw on "converging evidence from developmental neuroscience, on the one hand, and established developmental science findings from behavioral, cognitive, and social methodologies". ${ }^{27}$ While it is virtually universally accepted that an eighteen year old has the capacity to make the informed decision to join the armed forces, it should be acknowledged that generally eighteen year olds are not fully developed - indeed, they are still classified as adolescents. The World Health Organization defines adolescence as "the period in human growth and development that occurs after childhood and before adulthood", and includes ages 10 to $19 .^{28}$

The converging evidence suggests that during adolescence a "rapidly increasing capacity for adult level cognitive functions" is developed and attained; ${ }^{29}$ and that there is a plateau in cognitive development that is reached by late adolescence. Additionally, in isolated aspects of cognitive development, specifically speed of processing, there is a "positive growth inflection point" in early adolescence. ${ }^{30}$ However, Keating warns that testing for different features of cognitive function in isolation may well lose sight of the ability to employ these functions in day-to-day life. ${ }^{31}$ According to "dual process models", two interdependent cognitive systems influence one's cognitive functioning. The one system requires little

\footnotetext{
${ }^{27}$ Keating, 'The Evolving Capacities of the Child', p. 193; Daniel P. Keating, 'Cognitive Development' in B. Bradford Brown and Mitchel J. Pearlstein (eds.), Encyclopedia of Adolescence (Elsevier Academic Press: Amsterdam, 2011); Daniel P. Keating, 'Cognitive and Brain Development' Enfance (2012) 3, pp. 267-279.

28 'Maternal, newborn, child and adolescent health: Adolescent development' World Health Organization http://www.who.int/maternal child adolescent/topics/adolescence/dev/en/, accessed on 20 March 2017.

${ }^{29}$ Keating, 'The Evolving Capacities of the Child', p. 193.

${ }^{30}$ Ibid, p. 192.

${ }^{31}$ Ibid, pp. 191-194.
} 
cognitive effort, and accounts for instinctive judgment. The second system is based in the pre-frontal cortex, and requires more effort, and is analysis-based, instead of instinct-based. In adolescents, there is a "developmental maturity mismatch" meaning that there is an overreliance on the first mentioned cognitive system, which is impacted upon by an overactive limbic system. ${ }^{32}$

The capacity of children is affected by individual characteristics, such as ethnicity, gender, disability and age, but also by environmental factors, such as class, education and culture. The environmental setting of, and social expectations upon children is vastly different in different contexts. For instance, the median age in Niger is 15.3, whereas the median age in Japan is $46.9 .^{33}$ This suggests that a child in Niger should and likely does make a more active contribution to household income and chores, which may impact upon development. Considering that most developmental neuroscience and developmental science experiments and studies are performed in the US and Europe, and in lab settings, it is debatable to what extent these findings are transposable to other, real world settings. ${ }^{34}$

Invariably, children's rights commentators recognize that children are not merely passive subjects, but are active agents who can make informed decisions about matters that affect them. However, this approach is often adopted without giving due regard to the theoretical foundations of children's rights. Tobin has largely rejected the western, individualistic, conception of human rights in developing theory on the foundations of children's rights. Instead, he opts for a "relational conception of rights", in terms of which:

Children's rights under the CRC are not claims to be asserted against the state to be enjoyed in isolation from parents and family. On the contrary, there is an expectation that the realisation of children's rights will be deeply connected and interdependent with the exercise of parental rights, responsibilities and local customary practices. As such, the family, and indeed the community and culture in which a child lives, will be the context in which their rights will be understood, mediated and enjoyed. ${ }^{35}$

This approach is informed by the idea of the "evolving capacities of the child" as provided for in article 5 of the CRC:

\footnotetext{
32 Ibid, pp. 193-194.

33 The World Fact Book, Central Intelligence Agency of the United States, https://www.cia.gov/library/publications/the-world-factbook/fields/2177.html, accessed on 20 March 2017.

${ }^{34}$ Gerison Lansdown, 'Innocenti Insight: The Evolving Capacities of the Child' UNICEF (2005), p. 30.

${ }^{35}$ John Tobin, 'Fixed Concepts but Changing Conceptions: Understanding the relationship between Children and Parents under the CRC' in Martin D. Ruck, Michele Peterson-Badali and Michael Freeman (eds.), Handbook of Children's Rights (Abingdon: Routedge, 2016), p. 63; John Tobin, 'Justifying Children's Rights' International Journal of Children's Rights 21(2013), p. 424.
} 
States Parties shall respect the responsibilities, rights and duties of parents or, where applicable, the members of the extended family or community as provided for by local custom, legal guardians or other persons legally responsible for the child, to provide, in a manner consistent with the evolving capacities of the child, appropriate direction and guidance in the exercise by the child of the rights recognized in the present Convention.

Tobin convincingly argues, with reference to the work of Mayall, that children self-identify with such a relational, as opposed to individualistic, conception of their rights. ${ }^{36}$ The question emerges whether the evolving capacities of a sixteen or seventeen year old are such that, following the joint decision made together with parent(s) to enlist in the armed forces, that person can operate without receiving further direction and guidance from a legal guardian. Should that not be the case, it would suggest that there is a need for the armed forces to assume the role of the legal guardian - perhaps in loco parentis. On the other hand, should the child have the capacity to operate autonomously, no such formal relationship between the child and the armed forces will be required.

Keating notes, "Across the age range from infancy to age eighteen years, there are monumental differences in capacities with respect to both nurturance and selfdetermination". ${ }^{37}$ In his approach, Keating adopts Ruck's (et al) identification of four core rights that provides the foundation of the $\mathrm{CRC}$, these include: freedom from discrimination; the best interest of the child principle; the right to life, survival and development; and the right to participate and respect for the views of the child. From these core principles Keating extrapolates three categories of rights, into which all rights in the CRC can be divided: survival and development rights; protection or nurturance rights; and participation or selfdetermination rights. He classifies article 38 of the $\mathrm{CRC}$, containing the prohibition of child use and recruitment, as belonging to the category of protection or nurturance rights. His approach is justified by the fact that article 38 is aimed at the person using or recruiting the child, and remains silent on the decision made by the child to join the armed forces or group. Nevertheless, as the prohibition of child use and recruitment is the only provision of the CRC that departs from the younger-than-eighteen threshold, the CRC recognizes the implied capacity of the child to join the armed forces (in instances of voluntary enlistment), even without any parental consent required. As such, there is an element of participation or selfdetermination rights inherent in article 38. Undoubtedly article 3(3) of the CRC Protocol fall into the category of participation or self-determination rights, as it speaks specifically to the requirements for a child to voluntarily join the armed forces.

\footnotetext{
${ }^{36}$ B Mayall, 'The Sociology of Childhood in Relation to Children's Rights' International Journal of Children's Rights 8 (2000), p. 256; Tobin 'Fixed Concepts but Changing Conceptions', p. 63; Tobin 'Justifying Children's Rights', p. 424.

${ }^{37}$ Keating, 'The Evolving Capacities of the Child', p. 187.
} 
While the recognition of the child's evolving capacities in article 5 of the CRC provides a foundation for such participation or self-determination, article 12(1) explicitly identifies the participatory rights of the child:

States Parties shall assure to the child who is capable of forming his or her own views the right to express those views freely in all matters affecting the child, the views of the child being given due weight in accordance with the age and maturity of the child.

While the use of concrete age thresholds is useful from a legal perspective - indeed, this was the approach adopted in defining the child - the law can and does make provision for the unique developmental features of an individual child, through the recognition of the evolving capacities of the child and the child's right to express her or his views freely in all matters affecting her or him, with due weight being afforded to the age and maturity of the child. Using a defined age threshold as a lower limit to decision making (in the context of voluntary enlistment, sixteen or seventeen), while still requiring parental consent up to age eighteen, represents a balance between a values-based and instrumentalist approach to children's rights.

In the decisional matrix that precedes a child submitting an application to enlist in the armed forces, the child and the consenting parent(s)/guardian(s) engage in an informal consultative process, where, likely taking into account different factors, they reach consensus that it is in the overall interest of the child to submit her or his application. The implications of the direction and guidance of the parent that results in the joint decision to enlist are such that the parent recognizes the evolving capacities of the child to operate in a much more autonomous manner, once she or he is enlisted. This process speaks very much to parental guidance consistent with the evolving capacities of the child, as recognized by article 5 of the CRC. This negates the need for direct parental supervision once the child is a service member. Additionally, there is no requirement, from an international child rights perspective, that the armed forces assume a parent-like relationship in respect of the child, such as the in loco parentis doctrine. However, while international child rights do not require the recognition of such a formal relationship, the armed forces do owe an enhanced duty of care to child recruits, and the armed forces should adopt formal policy to reflect the nature of this duty of care. This is essential to ensure that both parental consent, and the child's decision to join voluntarily, is truly informed. Should a state wish to formally recognize a more stringent duty of care in respect of enlistees younger than eighteen, the state will be free to do so.

\section{The (Lack of an) Approach Adopted by States}


Many armed forces have cadet or similar programmes where young people are given exposure to the armed forces. While these programmes are patently aimed at attracting future enlistees, participation is often open to younger children, such as twelve-year-olds, and does not result in formal membership of the armed forces. The present discussion is aimed exclusively at the enlistment of persons younger than eighteen as members of the armed forces. The approaches adopted by Australia and the UK are considered, as Canada has not yet adopted a formal position in this regard.

\section{Australia}

In order to join the Australian Defense Force (ADF) an enlistee has to be seventeen on the date on which she or he formally enters the ADF. ${ }^{38}$ However, an application for enlistment can be submitted once the candidate is 16 years and 6 months old. ${ }^{39}$ While a seventeen year old can enlist in the ADF through the ordinary enlistment stream, the ADF specifically established an ADF Gap Year programme (ADFGY), which is open to enlistees aged between 17 and 24. The ADFGY is particularly attractive as, while participants are deemed "enlisted or appointed as Defence members and have the same or similar entitlements and requirements as all other Permanent or Reserve Defence members", the service commitment is only for one year, and the programme allows resignation. ${ }^{40}$ This implies that enlistment into the ADFGY must comply with article 3 of the CRC Protocol. Should an ADFYG participant whish to enlist for an ongoing form of service, she or he can do so at any time during the ADFGY, or immediately thereafter. Unfortunately, the eligibility requirements include that the enlistee be at least 18 on or before:

(1) completion of the Navy Recruit course in the Navy program;

(2) 31 May for participation in the Army program; or

(3) the scheduled graduation date of the relevant recruit training course in the Air Force program. ${ }^{41}$

The implication is that a person who wishes to submit their application to the ADF aged 16 years and 6 months, with the intention of joining the forces on the date of her or his seventeenth birthday, will qualify to join the regular forces, but will not qualify for the ADFGY. This may also result in a longer service commitment than is the case with an ADFYG participant.

\footnotetext{
${ }^{38}$ Enlistment into the Australian Forces is provided for in Article 34 of the Defence Act 103, Article 24 of the Naval Defence Act 1910 and Article 4E of the Air Force Act 1923.

${ }_{39}$ See, http://www.defencejobs.gov.au/army/how-to-join-the-army/eligibility-check/, accessed on 20 March 2017.

${ }^{40}$ Military Personnel Policy Manual (MILPERSMAN), Australian Department of Defense (October 2013), Part 2, Chapter 4.

${ }^{41}$ Ibid, 4-2.
} 
The ADF Military Personnel Policy Manual deals in considerable detail, and holistically, with the 'Management and Administration of Defence Members Under 18 Years of Age', and this policy is also applicable to ADFGY participants. Moreover, those sections of the Military Personnel Policy Manual that deal with members under the age of eighteen should be read with the ADF Youth Policy Manual. ${ }^{42}$ The ADF specifically recognizes an enhanced duty of care in respect of child enlistees:

Defence members under 18 are vulnerable people and Defence has a higher standard of duty of care for them. If a breach of duty of care is established and there is injury, loss or damage as a result of that breach, then negligence on the part of the Commonwealth can be established. ${ }^{43}$

This duty of care commences from the time when the member officially joins, and includes transportation from the place of recruitment to the training facility. In addition to such an enhanced duty of care, this section also indicates that the ADF do not exclude the application of general legislative provisions to members of the defense force, as some other states, including the UK do. Indeed, it is recognized that Commanding Officers (CO) and managers must take into account whether persons in their command need to comply with "Working with Children Checks" in line with legislation in the various States and Territories. This is dependent on the definition of "child-related work", which varies in different States and Territories. ${ }^{44}$

The ADF endeavors to give effect to its obligations in respect of child enlistees through its "Defense Youth Safety Framework", which includes a range of policies, and implementation tools and resources dealing with youth safety governance; risk management; incident response and responding and reporting; code of conduct guide; information disclosure; youth safety training; etc. The role of COs and managers in respect of youth protection of child enlistees is expressly recognized and defined. Where a $\mathrm{CO}$ or managers has child enlistees in their command, they are obliged to develop a risk management plan and standing orders. The risk management plan should address "youth safety risks and detail any control actions relevant to the unit or establishment, including tailored actions outlined in the Defence Youth Safety Framework" ${ }^{45}$ Standing orders should serve to "ensure that all

\footnotetext{
${ }^{42}$ The Youth Policy Manual also applies to roles occupied by persons younger than eighteen who are not deemed members of the ADF, such as cadets and work placement participants.

${ }^{43}$ MILPERSMAN, part 7, 5-2, at 5.11.

${ }_{44} \mathrm{Ibid}$, part 7, 5-5, 5.23-5.24.

${ }^{45} \mathrm{lbid}$, part 7, 5-5, 5.22.
} 
reasonable measures are taken to proactively manage specific risks relating to Defence members under $18,{ }^{46}$

There are features of ADF enlistment that need refinement, specifically ensuring that the age eligibility rules for the ADFGY programme overlap with those of the regular forcers, to ensure that all persons younger than eighteen who are eligible for enlistment can benefit from the ADFGY programme. Nevertheless, the holistic ADF policy shows genuine commitment towards compliance with the CRC Protocol, and with children's rights more broadly. The ADFs approach corresponds with the argument I made above, that while international children's rights do not require the recognition of a formal relationship between the child and the armed forces, the armed forces do owe an enhanced duty of care to child enlistees, and the armed forces should adopt formal policy to reflect the nature of this duty of care. This is achieved through the formal recognition of a higher duty of care in respect of child enlistees; a holistic policy that deals with a broad spectrum of issues that may arise in the context of child enlistees; the recognition of the applicability of general legislation to the protection of children; the development of the "Defense Youth Safety Framework"; and the formal recognition of and guidance for $\mathrm{COs}$ and managers regarding their responsibilities in respect of child recruits. In addition to reflecting the article 3 requirements in the CRC Protocol, the ADF has committed itself, where a person younger than eighteen is recruited in contravention of article 3, to "taking all reasonable measures to ensure that the member's service in the ADF is terminated as soon as practicable". ${ }^{47}$

The United Kingdom

The UK accepts many more applicants that are younger than eighteen than Canada or Australia, this is due to two primary reasons: an application for enlistment can be submitted once a person is aged fifteen years and seven months, and the person can be formally enlisted upon her or his sixteenth birthday (a year younger than Canada and Australia) ${ }^{48}$ and the ordinary school system in the UK is such that traditionally persons not intending to pursue university level studies will finish formal schooling aged sixteen, after having completed their GCSEs. Thus, traditionally, GCSE graduates would seek employment, or vocational training aged sixteen. This is reflected, in relevant part, in the declaration the UK entered upon ratifying the CRC Protocol:

\footnotetext{
${ }^{46} \mathrm{lbid}$, part 7, 5-6, 5.25 .

${ }^{47} \mathrm{lbid}$, part 7, 5-3, 5.15.

${ }^{48}$ The Armed Forces Act 2006 does not provide for a statutory minimum enlistment age. Instead, this is dealt with through a series of regulations, for example, section 13(a)(1) of The Armed Forces (Terms of Service) (Amendment) Regulations 2014 No. 3068 provides for a minimum age of recruitment into the Royal Air Force of sixteen.
} 
...The minimum age at which individuals may join the UK Armed Forces is 16 years. This minimum broadly reflects the minimum statutory school leaving age in the United Kingdom, that is the age at which young persons may first be permitted to cease fulltime education and enter the full-time employment market. ${ }^{49}$

The situation in this regard has changed since the enactment of the Education and Skills Act 2008 , which provides that while "schooling" is compulsory only to age sixteen, "education" is compulsory until age eighteen. ${ }^{50}$ The Act provides that "service as a member of the armed forces of the Crown" is to be treated as "working under a contract of employment". ${ }^{51} \mathrm{~A}$ person who has finished schooling, but is still of compulsory education age, may work under a contract of employment, if the person receives "sufficient relevant training or education", in terms of the Act. ${ }^{52}$ To comply with the legislation, the UK Armed Forces ostensibly had to affect changes to the manner in which enlistees younger than eighteen are trained. All socalled junior soldiers, who start their training aged between sixteen and seventeen years and five months, are trained at the Army Foundation College (AFC) in Harrogate, North Yorkshire. The AFC is responsible for "Phase 1 training", ${ }^{53}$ and runs two programmes: the longer 49 week course is designed for enlistees who will occupy roles requiring less "Phase 2 training", ${ }^{54}$ meaning role-specific training, for example, the infantry; whereas, the shorter 23 week course is designed for enlistees who will occupy roles requiring more Phase 2 training, for example, the Royal Army Medical Corps.

During the past three decades the UK armed forces have undergone two major stages of change with regards to policy on enlistment of persons younger than eighteen. Up until 1993, enlistment occurred in two streams: "junior entry" and "adult entry" (which included seventeen-year-olds). Junior entry included three strands, and the youngest recruits (specifically as apprentices) were fifteen years and eight months old. The crux of this system was to allow for separate, parallel training for junior entry (although seventeen-year-olds would still be trained as adult soldiers). During 1993, the armed forces adopted a "single entry" system. This system was such that all enlistees, regardless of age, would be trained in the same manner and at the same institutions. It was recognized that those under

\footnotetext{
${ }^{49}$ Declaration of the United Kingdom entered on upon ratification of the CRC Protocol.

${ }^{50}$ Section 1 of the Education and Skills Act 2008.

${ }^{51} \mathrm{lbid}$, section 62(1)(b).

52 Ibid, sections 5-8.

53 "Phase 1 military training has the common aim across the Services of taking civilians, a high proportion of whom are adolescents, and introducing them to the military way of life...". 'Third Report of Session 2004-2005', House of Commons Select Committee on Defence, p. 110 https://www.publications.parliament.uk/pa/cm200405/cmselect/cmdfence/63/6302.htm, accessed on 20 March 2017.

54 "Phase 2 non-officer training is the initial specialist training which gives Service personnel the necessary skills for their first employment." Ibid, p. 120.
} 
seventeen could not legally be trained to, for example, drive a vehicle, and combined training would mean a single standard, as such recruitment policy had to be such to ensure that younger enlistees were capable of meeting the same training demands as any other soldier.

However, unlike the example of Australia, UK policy in regards to the armed forces duty of care in respect of child recruits, or child protection more generally, is not publically available. Indeed, a number of policies in the UK are of concern regarding the enlistment of persons younger than eighteen. The minimum service obligation of a recruit who is older than eighteen is four years, however, where a recruit is younger than eighteen, the service obligation exists until the recruit's twenty-second birthday. ${ }^{55}$ This means that the service obligation of a sixteen year old is as much as six years, when compared to the four-year obligation of an eighteen year old. While this amounts to patent discrimination on the basis of age, Schedule 3 to the Equality Act 2010 excludes the application of the Act from "anything done for the purpose of ensuring the combat effectiveness of the armed forces" ${ }^{56}$ Indeed, there is a general trend of exclusion of members of the armed forces from legislative protection afforded to the public at large.

The lack of clear policy in respect of the armed forces duty of care became apparent after four recruits had died due to gunshot wounds while on guard duty at the Princess Royal Barracks, Deepcut, Surrey, between 9 June 1995 and 23 March 2002. ${ }^{57}$ All but one of these soldiers were younger than eighteen at the time of their enlistment, and two of them were aged younger than eighteen at the time of their deaths. ${ }^{58}$ The fourth death gained significant media attention, and it was at that point that the four deaths were linked publicly. These deaths gave rise to a number of inquiries and reports, the most significant being, the Deepcut Inquiry, which was an inquiry aimed specifically at these deaths and was conducted by Nicholas Blake QC, after appointment by the then Minister of State for the Armed Forces. ${ }^{59}$ These deaths also gave rise to a report by the Defence Committee of the House of Commons (HCDC) on the duty of care in the armed forces. ${ }^{60}$

\footnotetext{
${ }^{55}$ Ibid, paras. 59-74.

${ }^{56}$ Section 4(1) of the Equality Act 2010.

57 Nicholas Blake, 'The Deepcut Review: A review of the circumstances surrounding the deaths of four soldiers at Princess Royal Barracks, Deepcut between 1995 and 2002' House of Commons (29 March 2006).

${ }^{58}$ Sean Benton joined the British Army only after turning eighteen. Cheryl James, Geoff Gray and James Collinson all enlisted aged between sixteen and seventeen. At the times of their deaths Cheryl James was twenty, and Geoff Gray and James Collinson were both still seventeen. See Deepcut Review, pp. 93-204 \& 307-378.

${ }^{59}$ Ibid.

60 'Third Report of Session 2004-2005'.
} 
The Single Entry Implementation Plan (1993), which was a policy on recruitment into the armed forces, provided that "a Commanding Officer and/or Officer Commanding is in 'loco parentis' for soldiers under age 18". ${ }^{61}$ Nevertheless, in the course of the preparation of the duty of care report by the HCDC, the Ministry of Defence (MoD) submitted a legal memorandum arguing that COs and other commanders do not act in loco parentis of enlistees younger than eighteen, and indeed, the memorandum did not recognize a enhanced duty of care based on the status of the recruit as being younger than eighteen. ${ }^{62}$ This memorandum is premised on an unconvincing argument that the legal definition of a "child" is ambiguous. Essentially the argument is that in terms of specific legislation, such as the Criminal Justice and Court Services Act 2000, ${ }^{63}$ a person younger than eighteen may no longer be deemed a child. This approach is blind to the fact that majority is reached in the UK only upon the eighteenth birthday, and the international human rights standards, which the MoD agrees finds application, also dictates that a child is a person younger than eighteen, unless majority is attained at an earlier age. The MoD memorandum argues:

\begin{abstract}
Maturity and experience ... varies considerably between individuals, and Commanding Officers are directly responsible and accountable for ensuring that a pragmatic supervisory care regime is in place for all recruits, trainees and other students, whether aged $16 / 17$ or 18 plus.

[...]

The Services accordingly regard their "duty of care" responsibilities as arising from the employment of all individuals (including those under 18), and not arising from specifically acting "in loco parentis" to those within the 16-18 age group. A CO does not have the rights and obligations imposed on a parent or other guardian (such as a local authority looking after a child in care) in respect of a recruit who is a minor... However, the age of the recruit, the all-encompassing nature of initial training, and other factors particular to the recruit such as his or her maturity and intelligence would all be relevant to the degree of care required under the duty of care. It is, however, the case that the care and welfare of those under 18 merit particular attention, and COs are well seized of this need. The $\mathrm{CO}$ will always ensure appropriate involvement of the parents of a recruit or trainee, taking into account the wishes of the recruit or trainee. ${ }^{64}$
\end{abstract}

This ambiguous approach undoubtedly leads to vastly different levels of care and guidance being exercised by different commanders. Moreover, this approach fails to take account of the fact that the UK Armed Forces have particular, concrete obligations in respect of persons younger than eighteen, which it does not have in respect of persons older than eighteen. It is legally erroneous to argue that the duty of care owed by the armed forces is determined by

\footnotetext{
61 'Deepcut Review', para. 15b. The Single Entry Implementation Plan has been replaced, and the armed forces have moved away from recognizing such a formal relationship.

62 'Third Report of Session 2004-2005', written evidence, at EV262.

${ }^{63}$ According to this legislation a person in full time employment aged between sixteen and eighteen is not deemed a child.

64 'Third Report of Session 2004-2005', written evidence, at EV262.
} 
"the employment of all individuals (including those under 18)", ${ }^{65}$ and that no special duties exist in respect of those aged sixteen or seventeen. Indeed, there is a contradiction in agreeing to differing legal obligations in respect of persons younger than eighteen, specifically that they may not be used for direct participation in hostilities, but then arguing that there is no additional duty of care in respect of such enlistees. The Deepcut Inquiry also concluded that COs need to be made aware of the additional duty of care responsibilities that exist in respect of persons younger than eighteen. ${ }^{66}$

In its report, the HCDC concluded that the MoD had not accepted appropriate responsibility for recruits younger than eighteen, and that it needed to formulate policy in respect of the duty of care of enlistees younger than eighteen, "as if it acted in loco parentis" ${ }^{67}$ Additionally, the HCDC determined that it considered the lack of guidance on the duty of care responsibilities owed to those younger than eighteen "a serious failing by MoD" ${ }^{68}$ It appears that these recommendations have generally not been implemented. ${ }^{69}$ In their Third Report for the 2015-2016 Session, the HCDC again considered duty of care in the armed forces, specifically in relation to military training and exercises. ${ }^{70}$ This report did not address the duty of care owed to enlistees younger than eighteen at all, this was so notwithstanding the fact that of thirteen deaths that occurred in Phase 1 training between 1 January 2000 and 20 February 2016, five were persons younger than eighteen. ${ }^{71}$

There is not doubt that where an armed force recruit persons younger than eighteen, an enhanced duty of care arises as a matter of law. This is so simply by virtue of international children's rights obligations that arise through conventional and customary international law. Moreover, the states municipal law may contribute to the nature of this duty of case, as can be seen in the Australian example with the "Working with Children Checks", which are in line with legislation in the various States and Territories. In summary, of the three states included for analysis, Australia has acknowledged and defined the duty of care owed towards persons younger than eighteen in a fair amount of detail, and have taken a pro-children's rights approach. While the UK MoD has addressed the issue, it has largely shied away from

\footnotetext{
${ }^{65} \mathrm{lbid}$.

66 'Deepcut Review', para. 4.39 (p. 73).

67 'Third Report of Session 2004-2005', para. 69.

${ }^{68} \mathrm{lbid}$, para. 74.

69 "Commonsense and Understanding': Recommendations from the Defence Committee's Duty of Care Report that are still Outstanding 10 Years On' ForcesWatch (1 December 2015).

70 'Third Report of Session 2015-2016: Beyond endurance? Military exercises and the duty of care' House of Commons Select Committee on Defence, (20 April 2016) https://www.publications.parliament.uk/pa/cm201516/cmselect/cmdfence/598/598.pdf, accessed on 20 March 2017.

${ }^{71}$ Ibid, para. 3 (p. 5).
} 
recognizing an enhanced duty of care, and indeed, a number of recruitment practices and general legislative exclusions are very troubling in the UK context. Finally, the Canadian forces have, to date, not engaged with this issue directly.

\section{Military Justice and Child Enlistees in Conflict with the Law}

Military justice systems have been the subject of sustained attack by academics, non- and inter-governmental organizations, and civilian lawyers for the past few decades. At the heart of the discontent lies the critique that these systems do not comply with entrenched fair trial guarantees, particularly that one "shall be entitled to a fair and public hearing by a competent, independent and impartial tribunal established by law". ${ }^{72}$ However, these discussions go beyond the scope of the present article. Instead, we are concerned only with the implications of the international children's rights framework as it applies to child service members in professional armed forces who are in conflict with the law. To be clear, the international children's rights framework goes beyond procedural norms providing for fair trial guarantees, and includes substantive protection for "children alleged as, accused of, or recognized as having infringed the penal law". ${ }^{73}$ In this section, focus will shift away from the practice of Australia, Canada and the UK, as quite simply, none of these states have implemented targeted legislative provisions to provide for children in conflict with the military justice system.

In response to the challenges to the legitimacy of military justice systems, proponents of such systems argue that the demands for discipline within the military is particularly acute, and is different to those within civilian spaces. ${ }^{74} \mathrm{~A}$ number of states who enlist persons younger than eighteen, including the UK, Canada and Australia, maintain justice within the military through a separate military system, and this is unlikely to change. During the past two decades radical reforms have taken place in most military justice systems within professional armed forces, indeed, in many jurisdictions successful court challenges made reform of the military justice system unavoidable. These reforms were largely necessitated in order to insure a greater measure of independence and impartiality.

Military justice systems are heterogeneous in regards to the scope of jurisdiction ratione materiae, ratione personae, ratione loci and ratione tempore. ${ }^{75}$ However, a feature common

\footnotetext{
${ }^{72}$ Article 14(1) of the International Covenant on Civil and Political Rights (entered into force 23 March 1976) 999 UNTS 171 (ICCPR).

${ }_{74}^{73}$ Article $40(1)$ of the CRC.

${ }^{74}$ The Canadian Supreme Court accepted this view in $R v$ Généreux [1992], 1 S.C.R. 259 at 293.

${ }^{75}$ Gibson 'International Human Rights Law and the Administration of Justice through Military Tribunals', p. 6.
} 
to systems that developed from the British system and founded throughout the Commonwealth, including Australia and Canada, is that military justice is maintained through a two-tiered system, utilizing summary trials and courts-martial. Summary trials are conducted by officers in the chain of command, who are not legally trained, and they relate to disciplinary and conduct infractions, as Gilbert has succinctly stated: "the summary courtmartial ... is valuable when a military members needs to be taught a swift lesson that will serve as a message to others about to fall off the precipice of good order and discipline". ${ }^{76}$ Courts-martial are more akin to civilian criminal courts, they are: formal, presided over by a military judge, have entrenched procedural and evidentiary rules, and they try more serious offences usually of a criminal nature. ${ }^{77}$ The applicability of IHRL to courts-martial has not been seriously challenged. However, the question arises whether these rights guarantees applies only to courts-martial, or also to summary proceedings?

In Engel $v$. The Netherlands the ECtHR laid down a two-pronged approach to determine whether a charge with a disciplinary character should be deemed a criminal charge: 1) it should be determined whether "the provision(s) defining the offence charged belong, according to the legal system of the respondent State, to criminal law, disciplinary law or both concurrently"; and 2) more importantly, the nature of the offence and "the degree of severity of the penalty" may be decisive, even where the charge is framed as disciplinary. ${ }^{78}$ The Office of the Judge Advocate General of Canada has taken a different approach in arguing that summary trials are "by nature" criminal proceedings, as such, the ultimate sanction imposed is irrelevant to determining whether fair trial guarantees are applicable. ${ }^{79}$ Clearly the prevailing authority suggests that IHRL is applicable to summary proceedings by extension, additional rights guarantees applicable to children are to be adhered to where a child service member is subjected to a summary proceeding. From a fair trial perspective summary trials face severe challenges, for instance, the Commanding Officer (CO) acts as both prosecutor and judge, thus this system further challenges the notion of a fair and public hearing before a "competent, independent and impartial tribunal". 80

\footnotetext{
${ }^{76}$ Michael H. Gilbert, 'Summary Courts-Martial: rediscovering the Spumoni of Military Justice' 39 Armed Forces Law Review (1996), p. 119.

77 Gibson 'International Human Rights Law and the Administration of Justice through Military Tribunals', pp. 6-7.

${ }_{78}$ Engel v. The Netherlands (ECtHR, Plenary, Application No. 5101/71, 8 June 1976) 1 EHRR 647, at 84.

${ }^{79}$ Office of the Judge Advocate General, Canada, Summary Trial Working Group Report, Vol. I (2 March 1994), at $p$ 51, as cited by Aifheli E. Tshivhase, 'The Future of Military Summary Trials in the Modern Age' in Alison Duxbury and Matthew Groves (eds.), Military Justice in the Modern Age (Cambridge: Cambridge University Press, 2016), p. 354.

${ }^{80}$ Ibid, pp. 352-354.
} 


\title{
Children in conflict with the military justice system
}

Provisions of the CRC relevant to children in conflict with the law fall into the following categories: 1) the establishment of a specific justice system for children in conflict with the law; 2) the aims of juvenile justice, which, while there is overlap, is different to the aims of justice in respect of adults; 3) those provisions that overlap with adults in similar circumstances, such as the presumption of innocence; and 4) child-specific treatment, such as the rule that children should be detained separate from adults. The third category requires no further discussion, as the military justice system is obliged to be conducted consistent with these norms in the ordinary course of events. As such, focus will shift to the first, second and fourth categories. Discussion of the aims of juvenile justice and child specific treatment brings to the fore the question whether a child-specific justice system is necessary to give effect to a states broader obligations. As such, the establishment of a child-specific justice system will be discussed last.

The aims of juvenile justice

The aims of juvenile justice are very distinct from the aims of criminal justice more broadly. The CRC requires that "States Parties ... takes into account the child's age and the desirability of promoting the child's reintegration and the child's assuming a constructive role in society". ${ }^{81}$ The ICCPR reinforces this idea: "the procedure shall be such as will take account of their age and the desirability of promoting their rehabilitation" ${ }^{82}$ In its General Comment on the implementation of the rights of the child during adolescence, the CRC Committee provided:

\begin{abstract}
States parties are urged to introduce comprehensive juvenile justice policies that emphasize restorative justice, diversion from judicial proceedings, alternative measures to detention and preventive interventions... The focus should be on rehabilitation and reintegration... Detention should be used only as a measure of last resort and for the shortest appropriate period of time... ${ }^{83}$
\end{abstract}

In actions concerning children undertaken by courts of law and administrative authorities "the best interests of the child shall be a primary consideration". ${ }^{4}$ In sentencing, the CRC shows a strong preference towards non-custodial sentences, indeed, "the arrest, detention or imprisonment of a child shall ... be used only as a measure of last resort and for the shortest appropriate period of time". ${ }^{85}$ A much stronger emphasis is placed on the

\footnotetext{
${ }^{81}$ Article $40(1)$ of the CRC.

${ }^{82}$ Article $14(4)$ of the ICCPR.

83 'General Comment No. 20 (2016) on the implementation of the rights of the child during adolescence' Committee on the Rights of the Child CRC/C/GC/20 (6 December 2016), para. 88.

${ }^{84}$ Article $3(1)$ of the CRC.

${ }^{85}$ Article 37(b) of the CRC.
} 
reintegration of the child into a constructive role in society than is the case in respect of adults. $^{86}$ To this end, states parties are obliged to provide alternatives to institutional care, such as "care, guidance and supervision orders; counseling; probation; foster care; education and vocational training programmes" ${ }^{87}$ This is in order to be responsive to the wellbeing of the child, however, in regards to the appropriate sentence a key consideration is the proportionality between the circumstances of the child, and the nature and severity of the offence. $^{88}$

It was argued above that the evolving capacities of the child is relevant to establishing the legal relationship between the child and the armed forces. Similarly, the relatively advanced age of child enlistees (being at least sixteen) together with their evolving capacities, illustrated by their joining the armed forces, points strongly towards a more relaxed application of child-specific aims of punishment in the context of military justice. However, while the CRC applies to children from birth to age eighteen, which covers a massive spectrum of developent, the norms regarding children in the criminal justice system are, by definition aimed, at children in the older age groups - this has indeed been acknowledged by the CRC Committee. ${ }^{89}$ As such, too much emphasis should not be placed on the age of children in military service to argue for the mitigation of child-specific treatment in regards to prosecution and sentencing. These child-specific norms must be given effect to on a caseby-case basis. Even where the circumstances of a given child, and the nature and severity of the offence is such that a departure from the more rehabilitative framework for child justice is warranted, the Court has to apply its mind to child-specific aims of justice, and then point to the reasons why departure is warranted. This can never be done as a status-based determination, that is to say on the basis that the child serves in the armed forces. While the enactment of substantive and procedural provisions within the military justice framework is necessary to achieve this, it is equally necessary to ensure that those involved in the maintenance of military justice is sufficiently trained to give effect to the states child rights obligations.

Child-specific protection in criminal justice

The CRC provides for a number of specific protections in respect of children:

- Capital punishment and life imprisonment without possibility of release may not be imposed in respect of persons younger than eighteen at the time of the commission

\footnotetext{
${ }^{86}$ Article $40(1)$ of the CRC.

${ }^{87}$ Article $40(4)$ of the CRC.

${ }^{88} \mathrm{lbid}$.

89 'General Comment No. 10 (2007) Children's rights in juvenile justice' Committee on the Rights of the Child $\mathrm{CRC} / \mathrm{C} / \mathrm{GC} / 10$ (25 April 2007).
} 
of the offence, ${ }^{90}$

- Children deprived of liberty must be held separately from adults, unless the best interest of the children requires otherwise; ${ }^{91}$

- Children maintain the right to have contact with their families, except in exceptional circumstances; ${ }^{92}$

- Children accused of criminal offences must be informed promptly and directly of the charges against them, where it is appropriate, this should be done through their parents or legal guardians. Children also have the right to legal or other appropriate assistance in the preparation and presentation of their defence, ${ }^{93}$

- Children accused of criminal offences has the right to have "the matter determined without delay by a competent, independent and impartial authority or judicial body in a fair hearing according to law, in the presence of legal or other appropriate assistance and, unless it is considered not to be in the best interest of the child, in particular, taking into account his or her age or situation, his or her parents or legal guardians", 94

While many of these norms may be departed from, for example, "every child deprived of liberty shall be separated from adults unless it is considered in the child's best interest not to do so" (own emphasis), such departure cannot be justified simply by virtue of the fact that a given child is an enlistee, but need to be done on a case-by-case basis.

Child-specific justice systems

The CRC provides that "states parties shall seek to promote the establishment of" specialized, child-specific justice systems. ${ }^{95}$ These systems should allow, where appropriate and desirable, for non-judicial measures to be used in preference to judicial proceedings. ${ }^{96}$ In civilian justice systems states give effect to this obligation in a range of different manners, and indeed, the CRC does not provide much guidance on the exact nature of the

\footnotetext{
${ }_{91}^{9}$ Article $37(\mathrm{a})$ of the CRC.

${ }^{91}$ Article $37(\mathrm{c})$ of the CRC.

92 Ibid.

${ }^{93}$ Article 40(2)(b)(ii) of the CRC.

${ }_{94}$ Article 40(2)(b)(iii) of the CRC.

${ }^{95}$ Article 40(3) of the CRC.

${ }^{96}$ Article $40(3)(b)$ of the CRC.
} 
obligation. ${ }^{97}$ As a minimum, states are required to include child-specific provisions in their existing substantive and procedural criminal law. ${ }^{98}$

In the context of child enlistees, states have two options: 1) remove child enlistees from the personal jurisdiction of military justice; or 2) incorporate child-specific provisions into the substantive and procedural law that creates the military justice framework. Given the specific and different demands of military justice, with a strong focus on maintaining a disciplined force, the first option is not feasible at all. As such, states are obliged to give effect to the CRC obligations by, as a minimum, following the rout set out in option two. This approach will also allow states to comply with their obligation in terms of the aims of juvenile justice, and ensuring the proper implementation of child-specific protective norms.

\section{Conclusion}

A number of states, particularly continental European states, have largely subverted the issue of human rights compatibility of military justice systems by surrendering jurisdiction to civilian courts. This approach is well suited to give effect to child rights guarantees in respect of children in conflict with the law, including child enlistees. However, for many states, particularly common wealth nations, this solution is not viable. This is so due to a range of factors, including military efficiency, the different needs for justice in a military setting, and conceptions of military duty and tradition. The question thus emerges whether it is possible to make existing military justice systems child rights-compliant. The short answer is yes. In order to do so a state has to properly conceive of its duty of care in relation to child enlistees in a manner that is consistent with international child rights law; and the state has to legislate for a range of rights guarantees that gives effect to both the aims of juvenile justice, as well as child-specific protective norms, as provided for in the CRC. Gauging by the examples of Australia, Canada and the UK, there is an urgent need for states to consider its legal responsibilities in respect of child enlistees. Of these three states, Australia is the only one that has formally recognized an enhanced duty of care in respect of child enlistees. While Canada has not engaged with this issue in publically available policy directives or legislation, the UK presents the most concerning example, where it has actively been argued that there is no enhanced duty of care in respect of child enlistees. Even more striking, none of these states have made any legislative enactments to give effect to the aims of juvenile justice and to provide for child-specific protective norms in military justice context.

97 Ton Liefaard, 'Juvenile Justice from an International Children's Rights Perspective' in Wouter Vandenhole, Ellen Desmet, Didier Reynaert and Sara Lembrechts (eds.), Routledge International Handbook of Children's Rights Studies (London: Routledge, 2015), pp. 239-240.

${ }_{98}$ See also, Draft Principles Governing the Administration of Justice through Military Tribunals, 62d Sess., UN Doc. E/CN.4/2006/58 (13 January 2006), at paras. 26-28. 
While it goes without saying that a responsible state should always endeavor to act in a manner consistent with its domestic and international law obligations, not the least in situations affecting the rights of children, states who enlist persons younger than eighteen into professional armed forces have a particularly acute reason to do so. There is a massive movement, with significant momentum, against the enlistment of persons younger than eighteen. Those advancing this movement have generally based their efforts on the notion that children simply do not belong in the armed forces. To date, they have been slow to campaign on the failure of states to give proper effect to their legal obligations in respect of children once enlisted. Considering that the voluntary enlistment of children older than sixteen, in a manner compliant with the CRC Protocol is lawful, there is a significant entry point for the anti-child enlistment movement to campaign on the basis of that which is not lawful, i.e. the failure to apply the appropriate duty of care standard in respect of such children, and the failure to give effect to child rights obligation in respect of children in conflict with military justice systems. This is indeed an issue of considerable urgency. 